\title{
Study on Application of Divorce Relief System in Chinese Civil Code
}

\author{
Mingyu Hu, Xunan Luo \\ The Law School, Hainan University, Haikou, China \\ Email: humingyu79@163.com
}

How to cite this paper: Hu, M. Y., \& Luo, X. N. (2020). Study on Application of Divorce Relief System in Chinese Civil Code. Beijing Law Review, 11, 963-973. https://doi.org/10.4236/blr.2020.114057

Received: October 15, 2020

Accepted: December 18, 2020

Published: December 21, 2020

Copyright (c) 2020 by author(s) and Scientific Research Publishing Inc. This work is licensed under the Creative Commons Attribution International License (CC BY 4.0).

http://creativecommons.org/licenses/by/4.0/

\begin{abstract}
Articles 1088, 1090 and 1091 in Chinese Civil Code improve the divorce relief system based on Marriage Law in 2001. It allows the economic compensation system to apply in joint property system, improving the application conditions and methods of economic assistance. It increases the miscellaneous provisions for divorce damage compensation. In order to understand and apply the divorce relief system well, we should distinguish marital property system and set up different application conditions. In economic assistance system, the "affordability" can be judged according to the standard of the support duty between relatives such as brothers and sisters. In damage compensation system, the other serious faults should be correctly understood.
\end{abstract}

\section{Keywords}

Chinese Civil Code, Economic Compensation, Economic Assistance, Damage Compensation, Application Study

\section{Introduction}

The relief system on divorce can balance social wealth, realize correction justice, and undertake social responsibility (Wang, 2014). Relief system on divorce is an important part of marriage and family system in China, including economic compensation system, economic assistance system and damage compensation system. Among them, the economic compensation system focuses on acceptance of the value of domestic work; the economic assistance system focuses on giving economic help to the party who is economically disadvantaged, and helping her (him) get through the difficulties at the beginning of divorce; the damage compensation focuses on the "penalty" for one's serious fault behaviors, to realize the compensation and comfort to the spouse without fault. The three systems to- 
gether constitute a unique divorce relief system in China, which gives relief to the weaker spouses (notably women) or the injured party from different aspects, reflecting the principle of protecting the interests of women and keeping fairness.

On the basis of Marriage law in 2001, Chinese Civil Code has improved the relief systems on divorce in 2020. Article 1088 stipulates: "if one of the husband and wife takes more obligations for raising children, taking care of the elderly, assisting the other party in work, etc., he or she shall have the right to claim compensation from the other party at the time of divorce, and the other party shall make compensation. The specific measures shall be agreed upon by both parties; if no agreement is reached, the people's court shall make a judgment." It is about economic compensation deleting the restrictions on the application of the marital property system, and expanding its scope from separate property system to all marital property systems. Article 1090 states: "at the time of divorce, if one party has difficulties in life, the other party who can afford it shall give appropriate help. The specific measures shall be agreed upon by both parties; if no agreement is reached, the people's court shall make a judgment." It is about economic assistance, increasing the preconditions for the helping party to provide financial assistance, improve the mode of economic assistance. Article 1091: "in case of any of the following circumstances leading to divorce, the party without fault shall have the right to claim damage compensation: 1) bigamy; 2) cohabitation with others; 3 ) domestic violence; 4) maltreatment or abandonment of family members; 5) other serious faults." It is about damage compensation which adds miscellaneous provision to expand the scope of application. These new rules further improve the relief system on divorce. It is necessary to analyze and interpret the newly revised rules, which are related to the application effect of the divorce relief system after the implementation of Chinese Civil Code.

There are some issues deserving attentions. Is the application of economic compensation the same when marital property system is different? In the economic assistance system, how to judge whether a party has the ability to help? Are forms of housing assistance still applicable? In the divorce damage system, how to define "other serious faults"? This article will take article 1088, 1090 and 1091 of Civil Code as the main text, combined with other relevant provisions, to analyze and interpret the above rules.

\section{Application of Economic Compensation for Divorce}

The economic compensation for divorce refers to the system in which a husband or wife takes more obligations in raising children, taking care of the elderly and assisting the other party in work during the marriage, who has the right to ask compensation from the other party at the time of divorce. The economic compensation is mainly the compensation for the value of housework. The system was established when Marriage Law was amended in 2001, and now Chinese Civil Code has improved it again. 


\subsection{Expand the Scope of Application}

Article 40 of Marriage Law in 2001 limits the application of the economic compensation to the separate property system, excluding marital joint property system. But there are only $3 \%$ of couples apply the separate property system infact (Nuojun Sun, 2018). In practice the court will directly reject the litigant's claim on the basis that the husband and wife do not agree on separate property system. Compared with Article 40, article 1088 of Civil Code has made the greatest progress by deleting the restriction. Now the scope of application of the economic compensation system is expanded, not only the separate property system, but also various property systems, especially the joint property system are included.

In the case of separate property system, allowing the application of divorce economic compensation will help to realize the correct evaluation of the value of housework. In the case of joint property system, it is also necessary to correctly evaluate the housework taken by one party. Article 40 of Marriage Law is on the hypothesis that one can get enough compensation by separating joint property between husband and wife. But this is not the fact. Under the joint property system, if one party (usually the female party) is engaged in the creation of social value, at the same time he/she also engaged in most of the domestic work, his/her contribution to the family is "dual". It cannot reflect the evaluation of the domestic work simply by separating the joint property. Especially when there is no joint property to be separated, it will result in the "double" deprivation of the value of one's housework. The joint property system should also be included in the scope of divorce economic compensation system. It can evaluate objectively the contribution value of domestic work, and reflect the principle of consistance between rights and obligations (Wang, 2011). It can help the party who takes more obligations in the marriage get spiritual comfort and property relief at the time of divorce, which embodies the justice, compensation and protection (Yang, Long, \& Xia, 2006).

\subsection{The Application Conditions are Different in Different Property System}

The marital property system in China includes legal joint property system and contractual property system. And the contractual property system includes separate property system, general joint property system and limited joint property system (Chen, 2018a). The general joint property system refers to that, according to the agreement between the husband and wife, except for the special property, the property acquired by the husband and wife during the marriage and the property before marriage belong to the husband and wife jointly. The limited joint property system means that part of the property should be co-owned and part of the property should be owned separately. If the marital property system is different, is the applicable condition of economic compensation for divorce the same? 
Article 1088 of Civil Code stipulates that "if one of the husband and wife takes more obligations, he/she shall have the right to claim compensation from the other party." The above provision may probably lead to people's misunderstanding on the application of the system, thinking that as long as one of the husband or wife takes more obligations, he/she can ask for divorce financial compensation. In fact, there is no problem in the case of separate property system, but in the case of other property systems, it needs specific analysis.

In the case of separate property system, the premarital property and the property acquired during the marriage belong to each other separately. There is no joint property between the husband and wife, and there is no mutual sharing of property interests. At the time of divorce, there is no separation of the property between husband and wife. In this case, it is no problem for the party who takes more domestic obligations, to request financial compensation from the other party in accordance with Article 1088.

In the case of the joint property system, both parties share the joint property and the value created by each other, including social labor and domestic work. At the time of divorce, if one is allowed to have the right to claim for economic just because it meets the condition that "one takes more domestic obligations", it may be overcorrected and lead to a new imbalance. For example, in a couple, the man is responsible for making money to support the family, and the woman is responsible for caring for the children and the elderly. There is no surplus property for separation at the time of divorce, or the property from the separation is enough to reflect the compensation for the the housework. At this time, the couple's interests have been exchanged and balanced. If one party is allowed to exercise the right of economic compensation, this balance will be broken up. Therefore, in the case of the joint property system, the limited conditions should be added, that is, the party takes more domestic obligations cannot obtain sufficient compensation from the separation of the joint property (Wang, 2019). The purpose of the divorce economic compensation system is to realize the balance of the interests between the husband and wife. We should avoid overcorrection and a new imbalance. In the case of joint property system, whether she/he needs compensation or not depends on whether one can get enough compensation from the separation of the couple's property. If it can, there is no need to make additional compensation; if not, the other party should make corresponding compensation.

In addition, there are some similarities between the joint property system and the general joint property system or the limited joint property system. There is not only the sharing of property between husband and wife, but also the separation of common property between them. The application can be compared with the application under the joint property system.

\subsection{Typological Analysis of Families for Economic Compensation under Joint Property System}

In order to facilitate understanding and application, this part intends to have 
typological analysis of families for economic compensation under joint property system.

Case one, two-job families. In this family both husband and wife have made positive contributions to increase the joint property, and one of them not only has a positive contribution to the increase of the family property, but also reduces the negative loss by engaging in housework or assisting the other party's work. In this case, only separating the joint property may not reflect the correct evaluation of one's more domestic housework. The party who undertakes more housework should be allowed to ask for corresponding compensation.

How to compensate? Some scholars suggest that the value of compensation for housework $=($ the gap of annual income between husband and wife $\div 2) \times$ the duration of marriage. Some other scholars argue that the calculation method does not subtract the cost during the marriage. This is only one of the problems. Another problem is that a theoretical assumption of the calculation method is that the income of the compensated party is lower than that of the compensating one. If the income of the compensated party is equal to or higher than that of the compensating one, it will be unfair. Under the joint property, we should consider the compensation for one's domestic work from the separation of common property. First of all, the value of housework may be calculated according to the time, intensity, complexity and duration of marriage, with reference to the service remuneration level of market domestic service or similar types of work. Then the contribution of both to the accumulation of property is compared. If the value of housework can be made up by dividing the joint property, no compensation is needed. If not, it needs to be compensated.

Case two, Single profit families. In this family, during the existence of the marriage relationship, one party (usually the wife) undertakes more obligations to engage in housework or assist the other party in work, but there is no or a little property to be divided when they divorce. At the same time the other party has obvious or implicit benefits, such as obtaining qualification certificate, education certificate, working skills or obtaining intellectual property rights, etc. These intangible assets are inseparable, but they play an important role in one's future wealth creation. In this case, the contribution and the benefits are unbalanced. The party who undertakes more housework has made obvious sacrifice, and often his /her career development are greatly restrained (Xia, 2007). So he /she should be allowed to ask the other party for corresponding economic compensation. In this case, the amount of compensation should be determined according to the time, intensity, complexity of the work involved in family affairs, the personal development opportunities abandoned and the basic living standard of local residents.

Case three, Migrant worker families. In this family, during the marriage, one (usually the wife) takes care of the children and the elderly at home, while the other (usually the husband) goes out to work. The income from working is only enough for the expenses of the family, and there is no accumulation of common 
property. At this time, the contribution of the husband and wife to the marriage and family and the benefits obtained are balanced. Both sides have realized the exchange and sharing of their respective values. Any party should not ask for economic compensation from the other party even if she/he takes more domestic housework. There are lots of migrant workers' families in China.

Case four, full-time housewife families. In this family during the marriage, one (usually the wife) takes more housework, the other (usually the husband) earn more money. The party who does more housework can obtain corresponding compensation from the separation of joint property, and realize the compensation for housework, she should not ask for economic compensation.

The above is a typical analysis of the marriage and family under the joint property system. But in reality, the families are very complex and cannot be exhausted, and it needs to be analyzed in combination with the specific problems.

\section{Application of Economic Assistance for Divorce}

Economic assistance refers to that when a couple is divorced, the affordable party should provide corresponding material assistance to the other party who has real difficulties or special needs. The original intention of the system is to enable the party who has difficulties in life at the time of divorce to get the financial help to maintain a normal life. It reflects the protection for the weaker spouses, notably women. The economic assistance system is the extension of marital property effect at the time of divorce. It is a kind of aftercare measures for divorce, and the embodiment of substantive justice (Wang, 2010). The economic assistance system has a long history of development in China and has been constantly improved.

\subsection{Increase the Condition of Helping Party: "Affordability"}

Article 42 of Marriage Law in 2001 stipulates: "in case of divorce, if one party has difficulties in living, the other party shall give appropriate help from his/her housing and other personal property." This provision only considers the objective needs from one party, but not the affordability of the helping party. If one party is in difficulty and needs financial help, but the other party is unable to provide assistance due to lack of affordability. The economic assistance is unrealizable. The regulation lacks scientificity and rationality obviously. Article 1090 of Civil Code in 2020 increases the other party's "affordability" as a prerequisite for economic assistance, which makes up for the deficiency of Article 42. This is worthy of affirmation. To a certain extent whether the other party has the ability to help determines whether the economic assistance can be realized.

How to judge whether one party can afford it? This is not clear in Civil Code. Throughout Marriage Law and Civil Code, there are several articles in addition to the "affordability". Among them, Article 1074 of Civil Code stipulates the maintenance obligations between grandparents and grandchildren, and Article 1075 stipulates the maintenance obligations between brothers and sisters. There 
are some commonalities between the maintenance obligations of grandparents -grandchildren and brothers-sisters, and the financial assistance obligations of divorce. First, the maintenance obligation and assistance obligation are both conditional, and both are based on the premise that the supporting party or the helping party has "affordability". Secondly, this duty of support or help is of identity and ethics. The performance of the maintenance obligation is not only the need to realize the family support function, but also the requirement of family ethics. The parties of assistance obligation were once a husband and wife. Although the marriage relationship has been relieved after divorce, the obligation of economic assistance is the extension of marital property effect. It is also the requirement of family ethics, has a strong ethical and identity color. Thirdly, from the literal point of view, the legal concepts applicable to the three are the same, "affordability". In the same law, in order to maintain the unity and authority of law, the definition of the same concept should be the same. On the above analysis, "affordability" can refer to the judgment standard of affordability between grandparents and grandchildren and between brothers and sisters.

According to the degree or standard of support, the duty of support between relatives can be divided into symbiotic obligation and life support obligation. The symbiotic obligation, also known as the life maintenance obligation, is an unconditional maintenance obligation, that is, even if the supporters reduce their own living standards, they should also have dependants and themselves maintain the same living standard. Such as the maintenance between husband and wife and the foster of parents for minor children. The general life support obligation is a kind of conditional maintenance obligation, that is to say, maintenance obligations is only given within the limit of not reducing their own living standards, such as maintenance between brothers or grandparents-grandchildren (Chen, 2018b). During the marriage, the maintenance obligation between husband and wife is a kind of "symbiotic obligation". After divorce, the marriage relationship between them has been relieved, and the unconditional maintenance obligation has become the conditional life support obligation. So the helper only needs to give help to the demander within the limit of not reducing his/her living standard.

To sum up, whether the helper has the ability to help depends on whether he/she has any surplus after meeting his/her reasonable living needs (Yinan Ma, 2019). If there is a surplus, it can be regarded as having the affordability of economic assistance; otherwise, it is not. If the helper still has the first order of legal maintenance obligations (including spouse, children, parents), the key is to see whether there is any surplus after meeting the reasonable living needs of themselves and the first order legal maintenance obligors.

\subsection{Application of Housing Assistance Forms}

With regard to housing assistance, Civil Code has deleted the provision in Article 42 of Marriage Law in 2001 that "the other party shall give appropriate as- 
sistance from his /her housing and other personal property". There are many problems in the form of housing assistance in practice. On the one hand, the value of the house is relatively large. The rationality of helping in the form of ownership is questioned. In the other hand, if the helper has only one house, it is not convenient for the life of both parties after divorce. So the deletion of this provision in Civil Code is worth affirming. Then, after deletion, can the form of housing assistance still be applied? In fact this article is not a complete denial of the form of housing assistance, but weakens the emphasis on it in Article 42 of Marriage Law. The form of housing assistance is still applicable. The assistance in the form of housing can be applied, but it should be applied with cautions. We should pay attention to the following points. First, it is not recommended to apply the house ownership form unless both parties can reach an agreement. The court cannot forcibly apply the help of the house ownership form. Secondly, if there is only one house, the residence form should be avoided as far as possible. It is better to use the form of rent. If the helper has two or more houses, housing assistance forms should be determined by themselves through consultation. If the negotiation fails, the people's court may make a judgment of residence form according to the actual situation.

\section{Application of Damage Compensation for Divorce}

The damage compensation for divorce refers to the legal system that the fault party should compensate for the damage of the non-fault party if the marriage relationship is broken due to the serious fault of the husband or wife. Damage compensation system has the functions of filling up damage, spiritual comfort, prevention and punishment of illegal activities. The system was established in 2001 when Marriage Law was amended, and Chinese Civil Code improved it.

Article 46 of Marriage Law in 2001 only provides four kinds of legal situations for divorce damage compensation. The scope of application is too narrow to meet the needs of practice. For example, adultery having a child, because it is not listed in Article 46 of Marriage Law, some courts directly refuse the victim's claim. In order to protect the interests of the victim, some other courts support the victim's claim by other means. Part courts have extended the interpretation, including adultery having a child into the "cohabitation with others". Part courts bypass Article 46 of Marriage Law and directly apply Tort Law, demanding the actor to undertake tort liability. Strictly speaking, the judgment has broken through the provisions of the law, which is an expansive application of the existing provisions. The scope of application of Article 46 of Marriage Law is too narrow, which has caused certain difficulties to judicial practice. On the basis of the original provisions, Article 1091 of Civil Code adds "other serious faults" as a cover clause, which expands the application of divorce damages. How to interprete "other serious faults"? This part intends to interpret and analyze the identification of other serious fault behaviors from the two dimensions of general definition and type analysis. 


\subsection{General Definition of Other Serious Fault Behaviors}

What are the judgment factors for reference? First of all, from the nature of the behavior, the serious fault behavior is mainly manifested as serious violation of the husband and wife's duty of loyalty or serious infringement of the other party's personal rights and personality interests. According to Article 1091 of Civil Code, bigamy and cohabitation with others are serious violations of husband and wife's loyalty and serious infringement of each other's personality interests; domestic violence, maltreatment and abandonment are serious violations of the other party's personal rights and interests. From the above list, we can see that the negative evaluation of legislation on such behaviors, which is a good reference significance for the identification of other serious fault behaviors. Secondly, from the damage consequences of the behavior, the serious fault behavior often causes serious mental damage to the other party and eventually leads to divorce. From the behavior listed in this article, it will cause great spiritual damage to the other party. Whether it causes property damage or not does not affect the definition of the serious fault behavior. The violation of loyalty may not cause property damage to the party concerned. Finally, the objective evaluation on this kind of behavior is important. If a normal rational person's objective evaluation is negative, then the negative evaluation should be taken as the reference factor of "serious fault".

To sum up, the definition of other serious fault should be decided referring to the listed behavior, from the nature of the behavior, the damage caused to the other party, as well as the general people's evaluation of them.

\subsection{Analysis on the Types of Other Serious Fault Behaviors}

According to the above analysis, the "other serious fault behaviors" include but are not limited to the following acts:

\subsubsection{Other Behaviors That Seriously Violate the Loyalty Duty}

Other serious violations of husband and wife's loyalty duty refer to serious violations except for bigamy and cohabitation with others. For example, adultery having a child, long-term adultery, long-term or multiple prostitution, repeated whoring, etc. Adultery having a child violates loyalty between the husband and wife, infringes on the personality interests of the other party, and causes great spiritual damage. In addition, if one party has long-term adultery, prostitution or whoring for many times, his/her behavior not only seriously violates the duty of loyalty between husband and wife, but also infringes on the personality interests of the other party, causing great mental damage to the other party, and even makes the spouse face the risk of personal damage caused by infectious diseases. As for the occasional adultery or one night stand, it is the fault of the perpetrator for a moment. After all, people are emotional animals. The occasional extramarital sexual behavior can be adjusted by moral, and should not be included in "other serious faults" to prevent the abuse of the divorce damage compensation 
system.

\subsubsection{Other Acts That Seriously Infringe Upon the Personal Rights and Interests of the Spouse}

Other serious violations of spouse's personal rights and interests refer to those that seriously infringements except domestic violence, maltreatment and abandonment, including deliberately infecting the other party with serious infectious diseases and coercing his wife to engage in prostitution, etc. If one knows that he or she has a serious infectious disease, and deliberately conceals and allows the other to be infected, it will cause great personal damage and mental damage to the other. The act of coercing the wife to engage in prostitution is even more heinous. It is despised by the world and should be included in the behavior of "other serious faults".

\subsubsection{Serious Fraud in Marriage and Family}

There are some serious frauds and deceptions, such as fraudulent support, concealment of physiological defects, etc. Fraudulent support refers to the behavior that the wife conceals the truth and causes the husband to raise non biological children without knowing it. Fraudulent support will make the husband suffer double damages in economy and spirit, which is a serious infringement on the victim's personality interests, and may even cause the husband missing the best reproductive opportunity. If one conceals a serious disease before marriage, the other party may apply to the people's court to cancel the marriage and claim damages compensation from the fault party according to the provisions of Article 1053 and Article 1054.2 in Civil Code. However, if one conceals physiological defects such as lack of sexual competence or fertility, and the other party marry him/her without knowing, the aim of marriage can't be realized, and he/she will pay the opportunity cost and suffers great spiritual damage. Because physiological defects are not diseases, the victim can't claim damage compensation according to Articles 1053 and 1054 of Civil Code. Therefore, it should be listed as "other serious faults".

\section{Conclusion}

While the freedom of divorce has been fully protected by law, the negative impact of divorce on the parties and society can't be ignored. It is necessary to strengthen the protection for the weaker or the injured spouse in order to form a balance of the freedom of divorce. On the basis of marriage law, Civil Code has revised and improved the divorce relief system to a certain extent. It has important reference significance for the application of divorce relief system to accurately understand and grasp the newly revised content.

\section{Fund Projects}

China's Social Science Fund in the west of China (17XFX002): Study on the legislative problems and Countermeasures of Chinese kinship law from the pers- 
pective of legal history.

\section{Conflicts of Interest}

The authors declare no conflicts of interest regarding the publication of this paper.

\section{References}

Chen, W. (Editor-in-Chief) (2018a). Law of Marriage and Family Inheritance (Third Edition, p. 129). Beijing: China University of Political Science and Law Press.

Chen, W. (Editor-in-Chief) (2018b). Law of Marriage and Family Inheritance (Third Edition, p. 133). Beijing: China University of Political Science and Law Press.

Ma, Y. N. (2019). Law of Marriage and Family Succession (Fourth Edition, p. 140). Beijing: Peking University Press.

Sun, R. J. (2018). Research on the Legislation of Divorce Relief System. The Jurist, No. 6, 165.

Wang, G. Y. (2010). Gender Analysis of Economic Assistance System. Journal of Law, No. 7,73 .

Wang, G. Y. (2011). Divorce Relief System: Practice and Reflection. Law Forum, No. 2, 33 .

Wang, G. Y. (2014). Practical Worries and Functional Construction of Divorce Relief. Journal of Law, No. 10, 73.

Wang, G. Y. (2019). Compilation Strategy and System Trend of Marriage and Family in Civil Code. Legal Science, No. 6, 87.

Xia, Y. L. (2007). On the Freedom and Restriction of Divorce (p. 223). Beijing: China University of Political Science and Law Press.

Yang, D. W., Long, Y. F., \& Xia, Y. L. (2006). Marriage and Family Law (p. 189). Beijing: China Renmin University Press. 